\title{
EFFECT OF THE NITROGEN AND MAGNESIUM FERTILISATION ON YIELD AND ECONOMIC EFFICIENCY OF WINTER TRITICALE PRODUCTION
}

\begin{abstract}
Stanisław BIELSKI, Deparment of Agrotechnology, Agriculture Management and Agribusiness, Faculty of Environmental Management and Agriculture, University of Warmia and Mazury in Olsztyn, Oczapowskiego 8, 10-719 Olsztyn, Poland, stanislaw.bielski@uwm.edu.pl (corresponding author)

Jan FALKOWSKI, Deparment of Agrotechnology, Agriculture Management and Agribusiness, Faculty of Environmental Management and Agriculture, University of Warmia and Mazury in Olsztyn, Oczapowskiego 8, 10-719 Olsztyn, Poland, falk@ukw.edu.pl

The present investigations were undertaken, in which the winter triticale cultivar Twingo was examined, with the aim of analyzing production output, expressed by grain yield and its structure, as affected by different levels of nitrogen and magnesium fertilisation and assess and compare the economic efficiency of production technologies. This research encompassed the results of a three-year (2013-2015) field experiment conducted at the Research Station in Tomaszkowo near Olsztyn, Poland. The experiment was set up in a random, split-plot design, with four replications. The first order factor was nitrogen fertilisation $\left(\mathrm{kg} \mathrm{ha}^{-1}\right): 30,60,90,120$ and 150 . The second order factor was the level of magnesium fertilisation $\left(\mathrm{kg} \mathrm{ha}^{-1}\right): 0$ and $5 \mathrm{~kg} \mathrm{MgSO} \cdot 7 \mathrm{H}_{2} \mathrm{O}$. Statistical analysis of the results showed that the grain yield was significantly affected by the year of the trial, nitrogen and magnesium fertilisation, interaction of the first and second factors was not proven. The method based on the standard gross margin (SGM) was used for the economic evaluation of the three production technology differentiated costs levels. Three technologies with the highest, medium and lowest average yields were selected to the comparison. Differences in compared technologies concerned to the date and dose of nitrogen and magnesium fertilisation. Results showed, that increasing intensity of winter triticale technology in the field trial, caused the higher financial yield value of winter triticale, as well as direct costs and direct surplus. The direct surplus was higher by $24.4 \%$ between the lowest and the highest winter triticale technologies. The highest yield technology was characterized by the highest profitability.
\end{abstract}

Keywords: triticosecale, grain yield, yield components, nitrogen and magnesium fertilisation, intensity level of technology

\section{INTRODUCTION}

Triticale was designed in order to obtain a species which combines wheat's good quality of grain yield with the tolerance to abiotic and biotic stresses, i.e. a plant suitable for cultivation in unfavorable conditions, where the yielding of typical cereals is somewhat limited (Estrada-Campuzano et al., 2008; Villegas, 2010; EstradaCampuzano et al., 2012). The yield of winter triticale and its quality depends on a number of factors. One of the major agrotechnical factors which affect grain yield and enable farmers to take advantage of the high production potential of cereals is mineral fertilisation, especially nitrogen nutrition (Gibson et al., 2007; Lestingi et al., 2010; Zečevic et al., 2010). The quantitative dimension of nitrogen is directly related to the efficiency of fertilisation. Fertilisation in every farming system is a very important element of agrotechnology, which determines the production effects. Actions aimed at improving the efficiency of the use of fertilizers are very important and desirable, they involve, among other things, the reduction of financial inputs and improvement of product quality (Jaśkiewicz, 2002; Podolska et al., 2002).

Magnesium ( $\mathrm{Mg}$ ) is a very important element for soil properties and plant growth (Staugaitis, Rutkauskiene 2010), involved in many enzyme activities and the structural stabilization of tissues (Gou et al., 2016), resistance and tolerance of plants to stress environmental factors (Mengutay et al., 2013). In Poland about 50\% of the area of agricultural land is characterized by a low content of absorbed magnesium, so mineral magnesium fertilisation is increasingly important (Sienkiewicz, 1994). According to Lipiński (2000) the important problem of plant nutrition is soil acidification in Poland and the accompanying deficit of magnesium. Błaziak (2007) reports that fertilisation in the form of $\mathrm{MgSO}_{4}$ does not decrease the soil $\mathrm{pH}$ but supplies magnesium and sulfur, which positively affects the spring barley yield.

The research hypothesis assumes a significant increase in productivity and economic efficiency of production by increasing the dose of nitrogen fertilizers and introducing magnesium for winter triticale fertilisation .

Copyright (C) 2017 The Authors. Published by Aleksandras Stulginskis University. This is an open-access article distributed under the terms of the Creative Commons Attribution License (CC-BY 4.0), which permits unrestricted use, distribution, and reproduction in any medium, provided the original author and source are credited. 


\section{MATERIAL AND METHODS}

Field experiment with winter triticale carried out over 2013-2015 in Didactic and Experimental Station in Tomaszkowo near Olsztyn ( $\mathrm{N}=53^{\circ} 71^{\prime} 74^{\prime}$ '; E=20 40'62'). The experiment was set up in a random, split-plot design, with four replications, on a light clay soil, classified as to a good wheat complex (Tab. 1). Tillage was applied according to conventional method, without simplification. The forecrop of winter triticale in the three-year research period was winter oilseed rape. The first order factor was nitrogen fertilisation $\left(\mathrm{kg} \mathrm{ha}^{-1}\right)$ : A - 30, B - 60, C - 90 (60+30), D - 120 (90+30), E - 150 (90+60). Doses of nitrogen equal 30 and $60 \mathrm{~kg} \mathrm{~N} \mathrm{ha}^{-1}$ were applied in early spring (BBCH 27). Higher doses (90, 120, $150 \mathrm{~kg} \mathrm{Nha}^{-1}$ ) were applied on two dates: in the resumed plant growth (BBCH 27 and $\mathrm{BBCH} 38)$. The second order factor was magnesium fertilisation $\mathrm{kg} \mathrm{ha}^{-1}$ $\mathrm{MgSO}_{4} \cdot 7 \mathrm{H}_{2} \mathrm{O}$ (magnesium sulphate heptahydrate dissolved in $951 \mathrm{ha}^{-1}$ ): $\mathrm{a}-0, \mathrm{~b}-5$. The plant protection against fungal diseases consisted of seed dressing Baytan Universal 094 FS (active ingredient triadimenol + imazalil + fuberidazol), and the spraying of plants with the preparation Input $460 \mathrm{EC}$ in dose of $1 \mathrm{lha}^{-1}$ (spiroksamina + protiokonazol) during the first node phase (BBCH 31). Weeds were controlled by a single autumn spray of a mixture of herbicides Dicuran $80 \mathrm{WP}$ in dose of $1 \mathrm{~kg}$ ha ${ }^{-1}$ (chlorotoluron) oraz Gold $450 \mathrm{EC}$ in dose $1.21 \mathrm{ha}^{-1}$ (2,4-D ester + fluroksypyr). Phosphorus and potassium fertilisation was applied before sowing in the total amounts of $30 \mathrm{~kg} \mathrm{P} \mathrm{ha}^{-1}$ and $75 \mathrm{~kg} \mathrm{~K} \mathrm{ha}^{-1}$. Dressed seed material was sown at the density of 300 germinating kernels per $1 \mathrm{~m}^{-2}$. The plot area was $15 \mathrm{~m}^{-2}$. The results were submitted to analysis of variance in a Statistica®10 software package. Tukey's test at the significance level of 0.05 was run to evaluate the significance of differences. The economic efficiency of winter triticale grain production was assessed for the lowest, middle and the highest yield in the experiment, using a quartile as a statistical instrument. The calculations were made using Standard Gross Margin methodology (SGM). Also, a synthetic measure of economic efficiency of production was used, in the meaning of direct profitability index achieved as the ratio of production value to direct costs incurred by generating this production. The calculations were made on three-year average yields of winter triticale grain. The prices of the production means were adopted from the fourth quarter of 2017 and converted into EUR at the actual exchange rate ( $1 €-4.27$ PLN).

Table 1. Chemical soil properties

\begin{tabular}{|c|c|c|c|}
\hline \multirow{2}{*}{ Specification } & \multicolumn{3}{|c|}{ Vegetation period } \\
\hline & 2013 & 2014 & 2015 \\
\hline Soil type & \multicolumn{3}{|c|}{ proper brown soil } \\
\hline Soils species & \multicolumn{3}{|c|}{ light clay } \\
\hline Soil pH (1 M KCL) & 5.5 & 5.7 & 6.0 \\
\hline Soil valuation class & \multicolumn{3}{|c|}{$\mathrm{R}-\mathrm{IVa}$} \\
\hline Soil suitability complex & \multicolumn{3}{|c|}{ good wheat } \\
\hline \begin{tabular}{ll}
\multicolumn{3}{l}{ Content of nutrients $\left(\mathrm{mg} \mathrm{kg}^{-1}\right.$ of soil $)$} \\
$-\quad \mathrm{P}$ \\
- & $\mathrm{K}$ \\
- & $\mathrm{Mg}$ \\
- & $\mathrm{N}_{\min }(0-90 \mathrm{~cm})$ \\
\end{tabular} & $\begin{array}{c}27.4 \\
26.7 \\
4.7 \\
19.4 \\
\end{array}$ & $\begin{array}{c}25.8 \\
24.9 \\
5.3 \\
18.5 \\
\end{array}$ & $\begin{array}{c}26.5 \\
27.2 \\
5.1 \\
17.2 \\
\end{array}$ \\
\hline
\end{tabular}

The three years when the field experiments were conducted were highly varied in the weather conditions, especially in the distribution of rainfalls during the growing season (Fig. 1). This had a direct impact on the growth and development of winter triticale. In the analysed seasons, the early autumn plant growth was accompanied by rainfall shortages and temperatures higher than multi-annual average. In the growing seasons April was a dry and warm month. Precipitation higher than the average occurred in July 2013, were triticale harvest was particularly troublesome. The rainfall was as much as $50 \%$ higher than the multi-year mean.

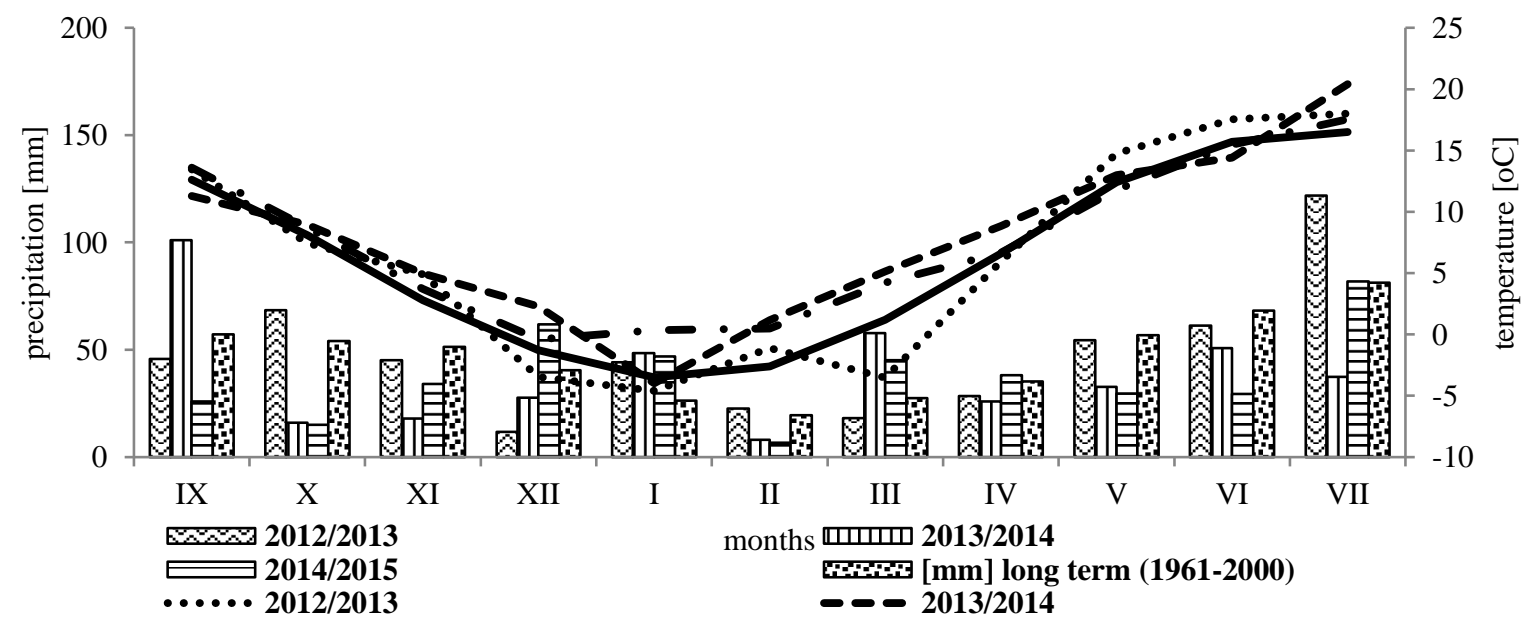

Figure 1. Rainfall and temperature distribution during the growing seasons 


\section{RESULTS AND DISCUSSION}

The number of spikes per $1 \mathrm{~m}^{-2}$ of a field depended on the growing season (Tab. 2). The highest value of this trait was recorded in 2015. Significantly fewer spikes per land unit were determined in 2013 and 2014 (decrease about $2.6 \%$ ). A tendency was noticed for a higher number of spikes per square meter on a field fertilized with growing nitrogen and magnesium doses. Researches Chwil (2014) shows that more spikes number winter wheat from the surface unit was recorded from objects with magnesium fertilized but was not a significant difference.

Table 2. Grain yield and yield components of winter triticale as affected by year, $\mathrm{N}$ and $\mathrm{Mg}$ fertilisation

\begin{tabular}{|c|c|c|c|c|c|c|c|c|c|c|}
\hline \multirow[t]{2}{*}{ Treatment } & \multicolumn{4}{|c|}{ Yield $\left(\mathrm{t} \mathrm{ha}^{-1}\right)$} & \multicolumn{2}{|c|}{1,000 grains weight $(\mathrm{g})$} & Grain number in ear & \multirow{2}{*}{$\begin{array}{c}\begin{array}{c}\text { Grain } \\
\text { weight/ear }\end{array} \\
2013-2015\end{array}$} & \multicolumn{2}{|c|}{ Number of ears per $1 \mathrm{~m}^{2}$} \\
\hline & 2013 & 2014 & 2015 & mean & 2013 & 20142015 mean & 201320142015 mean & & 2013 & 20142015 mean \\
\hline \multicolumn{11}{|l|}{$\mathrm{N}$ rate $\left(\mathrm{kg} \mathrm{ha}^{-1}\right)$} \\
\hline 30 & 6.73 & 6.71 & 6.81 & 6.75 & 36.7 & $\begin{array}{llll}38.9 & 41.0 & 38.9\end{array}$ & 37.437 .136 .637 .0 & 1.35 & 513 & $\begin{array}{lll}553 & 578 & 548\end{array}$ \\
\hline 60 & 8.21 & 7.28 & 7.34 & 7.61 & 35.9 & $\begin{array}{lll}38.2 & 39.9 & 38.0\end{array}$ & $\begin{array}{llll}38.6 & 36.1 & 38.2 & 37.6\end{array}$ & 1.36 & 613 & $\begin{array}{lll}531 & 595 & 580\end{array}$ \\
\hline 90 & 8.93 & 8.45 & 8.38 & 8.59 & 36.2 & $\begin{array}{lll}38.5 & 39.6 & 38.1\end{array}$ & $\begin{array}{llll}39.2 & 38.4 & 39.8 & 39.1\end{array}$ & 1.41 & 615 & $621 \quad 613 \quad 616$ \\
\hline 120 & 9.27 & 9.26 & 8.81 & 9.11 & 34.6 & $\begin{array}{lll}36.7 & 39.0 & 36.8\end{array}$ & $\begin{array}{llll}41.1 & 39.9 & 40.2 & 40.4\end{array}$ & 1.44 & 623 & $641 \quad 634 \quad 633$ \\
\hline 150 & 9.13 & 8.93 & 9.11 & 9.06 & 34.0 & $36.238 .6 \quad 36.3$ & $\begin{array}{llll}40.3 & 40.2 & 42.0 & 40.8\end{array}$ & 1.40 & 621 & $\begin{array}{lll}628 & 645 & 631\end{array}$ \\
\hline \multicolumn{11}{|c|}{$\operatorname{Mg}$ rate $\left(\mathrm{kg} \mathrm{ha}^{-1}\right)$} \\
\hline 0 & 8.31 & 7.85 & 7.93 & 8.03 & 35.3 & $\begin{array}{lll}37.5 & 39.1 & 37.3\end{array}$ & $\begin{array}{llll}40.1 & 38.1 & 38.7 & 39.0\end{array}$ & 1.36 & 591 & $\begin{array}{lll}581 & 603 & 592\end{array}$ \\
\hline 5 & 8.59 & 8.41 & 8.25 & 8.42 & 35.7 & $\begin{array}{lll}38.0 & 39.9 & 37.9\end{array}$ & $\begin{array}{llll}38.5 & 38.7 & 40.2 & 39.1\end{array}$ & 1.39 & 605 & $609 \quad 621 \quad 612$ \\
\hline mean & 8.45 & 8.13 & 8.09 & - & 35.5 & $37.739 .6 \quad-$ & $\begin{array}{llll}39.3 & 38.3 & 39.4 & -\end{array}$ & 1.38 & 597 & $595613 \quad-$ \\
\hline \multicolumn{11}{|l|}{ HSD (0.05) } \\
\hline Year $(\mathrm{Y})$ & \multicolumn{4}{|c|}{0.23} & \multicolumn{2}{|r|}{2.27} & \multicolumn{2}{|r|}{ n.s. } & \multicolumn{2}{|r|}{11.1} \\
\hline Nitrogen (N) & \multicolumn{4}{|c|}{0.19} & \multicolumn{2}{|r|}{1.37} & \multicolumn{2}{|r|}{ n.s. } & \multicolumn{2}{|r|}{ n.s. } \\
\hline Magnesium (M) & \multicolumn{4}{|c|}{0.35} & \multicolumn{2}{|r|}{ n.s. } & \multicolumn{2}{|r|}{ n.s. } & \multicolumn{2}{|r|}{ n.s. } \\
\hline $\mathrm{YxN}$ & \multicolumn{4}{|c|}{0.40} & \multicolumn{2}{|r|}{ n.s } & \multicolumn{2}{|l|}{ n.s. } & \multicolumn{2}{|r|}{ n.s. } \\
\hline YxM & \multicolumn{4}{|c|}{0.31} & \multicolumn{2}{|r|}{ n.s. } & n.s. & n.s. & \multicolumn{2}{|r|}{ n.s. } \\
\hline
\end{tabular}

others interaction n.s.

The number of grains in a spike was significantly conditioned by the nitrogen fertilisation level. As the amount of applied nitrogen increased, the yield achieved a higher value. Application of $90 \mathrm{~kg} \mathrm{~N} \mathrm{ha}^{-1}$ caused that the number of grains per spike in winter triticale increased significantly. The highest dose of $150 \mathrm{~kg} \mathrm{~N} \mathrm{ha}^{-1}$ had a positive effect on the number of grains per spike, but the difference was not significant relative to dose $90 \mathrm{~kg} \mathrm{~N} \mathrm{ha}^{-1}$. The current results confirm the reports by Dopka (2006), and Bielski (2015).

Nitrogen fertilisation did not play any significant role in the formation of grain weight per spike. Similar results were reported by Dopka (2006) and Bielski (2015). There was a tendency to increase the seed weight from a single spike with increasing intensity of nitrogen and magnesium fertilisation.

The statistical analysis proved that the 1,000 grains weight was significantly affected by the year of experiment, and nitrogen fertilisation. The lowest 1,000 grains weight was in 2013 (35.2 g), while the highest one was in the third year (39.4g). The references indicate that the 1,000 grains weight of triticale ranges from 35 to $55 \mathrm{~g}$ (Erekul, Köhn 2006; Kozak et al., 2007). Nitrogen nutrition affected this trait adversely, but this effect was not unidirectional. In general, the 1,000 grains weight was decreasing as the doses of nitrogen fertilizer increased. The most robust grain was harvested from the plot which had received the lowest nitrogen fertilisation. Significantly lower values of the 1,000 grains weight were recorded on the plots treated with $120 \mathrm{~kg} \mathrm{~N} \mathrm{ha}^{-1}$ compared to the ones supplied with $30 \mathrm{~kg} \mathrm{~N}^{-1}$. Samborski et al. (2008) also showed that the highest dose of nitrogen had a negative effect on the 1,000 grains weight. In the study by Alaru et al. (2004), a dose of nitrogen above $60 \mathrm{~kg} \mathrm{ha}^{-1}$ did not have any significant influence on the 1,000 grains weight. Mut et al. (2005) observed a significant increase of the 1,000 grains weight under the influence of nitrogen fertilisation. In our researches, grain weight did not depend on the intensity of magnesium fertilisation. There was, however, a greater weight of 1,000 grains after magnesium application. Similar trends in winter wheat research have been reported Chwil (2014) and Jankowski et al. (2016).

Our statistical analysis of the results demonstrated a significant effect of the year of the experiments on the yields of winter triticale. The year 2015 was the least favorable for the winter triticale grain yield. Triticale produced significantly higher and similar grain yields in 2013 and 2014 (Tab. 2). Among the most important factors affecting grain yields, Biberdžić et al. (2013) mentioned the climate. The difference in grain yields between the best and the worst year was $4.5 \%$. In the all growing seasons in response to the subsequently higher nitrogen doses up to $120 \mathrm{~kg} \mathrm{~N}^{-1}$, the grain yield increased significantly. The response of triticale to nitrogen was slightly different in the second year of the experiment. A significant decrease in grain yield was noticed following the application of $150 \mathrm{~kg} \mathrm{~N} \mathrm{ha}^{-1}$. Mut et al. (2005) obtained the highest grain yield of triticale supplied with a dose of nitrogen equal $180 \mathrm{~kg} \mathrm{ha}^{-1}$. A dose of nitrogen above $60 \mathrm{~kg}$ ha${ }^{1}$ in the study by Alaru et al. (2004), and a dose above $66 \mathrm{~kg} \cdot \mathrm{ha}^{-1}$ in the experiment by Gibson et al. (2007) did not affect significantly the grain yield. In our trials, a significant increase in grain yields (by $0.86 \mathrm{t} \mathrm{ha}^{-1}$ ) was observed after an application of just $60 \mathrm{~kg} \mathrm{~N} \mathrm{ha}^{-1}$. Małecka et al. (2004) reported that the grain yield from winter triticale increased 
significantly as the nitrogen fertilisation was gradually elevated to $120 \mathrm{~kg} \mathrm{ha}^{-1}$. Its further increase did not cause a significant difference in the volume of grain yields. In the trial run by Dopka (2006), the effects of 100 and $150 \mathrm{~kg} \mathrm{~N}^{-}$ ${ }^{1}$ were similar. Samborski et al. (2008) demonstrated a yield-stimulating effect of nitrogen at a dose rising up to $80 \mathrm{~kg} N$ $\mathrm{ha}^{-1}$, with an average yield increase of $21 \%$, and following the application of $170 \mathrm{~kg} \mathrm{~N} \cdot \mathrm{ha}^{-1}$, when a $9.2 \%$ yield increase occurred. The year and nitrogen fertilisation interaction shows that the highest triticale grain yield was obtained in 2013 from plots fertilized with a dose of nitrogen equal to $150 \mathrm{~kg} \mathrm{ha}^{-1}$. The lowest yield was determined in 2014 on plots fertilized with a dose of $30 \mathrm{~kg} \mathrm{~N} \mathrm{ha}^{-1}$. The higher yields of triticale were obtained from plots with magnesium fertilisation. On average, during the trial period, triticale fertilized with this fertilizer yielded $0.39 \mathrm{t} \mathrm{ha}^{-1}$ higher $(4.6 \%)$ than without fertilisation with magnesium. Higher yields from plots fertilized with magnesium were recorded in all years of research. Chwil (2014) also recorded higher yields from plots fertilised with magnesium $\left(0.2 \mathrm{tha}^{-1}\right)$, but these were not significantly different. Alaru et al. (2009) concluded that the strongest influence on yield and yield structure was by the year of an experiment, followed by a cultivar and the nitrogen fertilisation dosage.

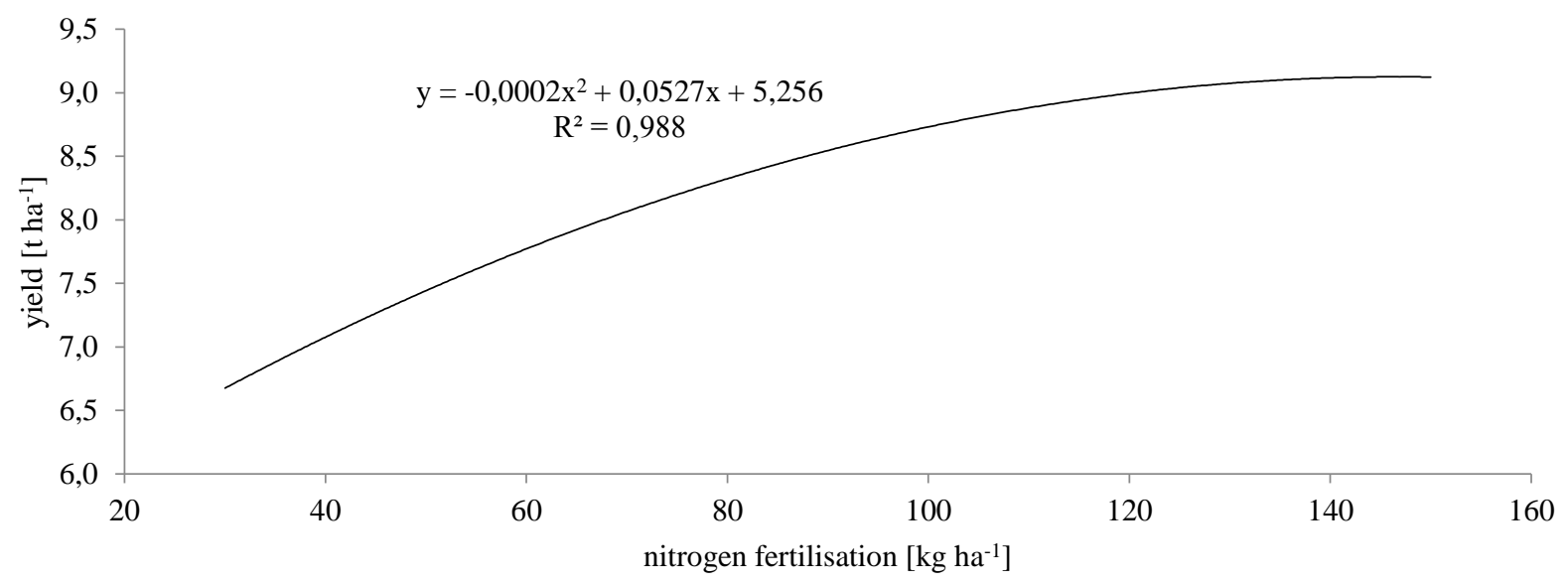

Figure 2. Regression curve of grain yield of winter triticale cv. Twingo depending on nitrogen fertilisation dose

Grain yields of winter triticale variety Twingo were quite high. The reason could be the cultivation of triticale after a very good forecrop and content of mineral nitrogen in the soil. From the calculated regression equation between the dose of nitrogen and grain yield, which is a second-degree curve, it follows that the maximum yield of grain in a field experiment with the variety Twingo can be achieved at $132 \mathrm{~kg} \mathrm{ha}^{-1} \mathrm{~N}$ (Fig. 2).

\section{Economic efficiency}

For producers, economic efficiency is much more important than agricultural efficiency. The importance of cost accounting and profitability on farm production is due to the need to rationalize all factors of production. The cost accounting provides the material for analysis and influences the formation of the production structure on the farm. This effect is even greater, when the connection between the farm and the market is stronger.

One of the most important elements of the economic assessment is the obtained value of direct surplus (Ziętara, 2002; Artyszak, Kucińska 2005).

Table 3. Production value and direct costs of the winter triticale production $\left(€ \mathrm{ha}^{-1}\right)$

\begin{tabular}{|l|c|c|c|}
\hline \multirow{2}{*}{\multicolumn{1}{|c|}{ Specification }} & \multicolumn{2}{|c|}{ The intensity level of technology } \\
\cline { 2 - 4 } & the lowest yield & the middle yield & the highest yield \\
\hline Grain yield $\left(\mathrm{t} \mathrm{ha}^{-1}\right)$ & 6.72 & 8.23 & 1,94 \\
\hline Production value $\left(€ \mathrm{ha}^{-1}\right)$ & 881 & 1,079 & 323 \\
\hline Directs costs $\left(€ \mathrm{ha}^{-1}\right)$, including: & 250 & 305 & 198.9 \\
mineral fertilizers & 125.8 & 180.6 & 51.5 \\
grain sowing & 51.5 & 51.5 & 73.1 \\
plant protection products, including: & 73.1 & 73.1 & 9.1 \\
seed dressing & 9.1 & 9.1 & 36.5 \\
fungicides & 36.5 & 36.5 & 27.4 \\
herbicides & 27.4 & 27.4 & \\
\hline
\end{tabular}

In climatic and soil experimental conditions, the level of winter triticale yield was high and ranged from 6.72 to $8.94 \mathrm{t} \mathrm{ha}^{-1}$. The highest yield technology provided a more favorable grain yield by $24.8 \%$ compared to the lowest yield technology (Table 3). However, this technology required $22.6 \%$ direct costs. The direct surplus was $24.4 \%$ higher in the highest technology than in the lowest yield technology (Tab. 4). Similar results were obtained in previous studies by Bielski (2014). Grabiński et al. (2008) achieved different results. The authors calculations showed that with low-input technologies achieved the highest direct surplus. Increasing intensity level direct surplus declined. Nieróbca et al. (2008) achieved similar results. Researches obtained higher direct surplus in the moderately intensive and economical technologies production of winter triticale. The direct costs per $1 €$ direct surplus, was slightly better in the highest yield 
technology (0.38). Augustyńska-Grzymek (2007) reported that the above indicator at the best producers of winter triticale is 0.31 . In our experiment, the difference between the compared technologies in the direct surplus per $1 \mathrm{t}$ of product were at a similar level.

Table 4. Economic evaluation of the winter triticale production

\begin{tabular}{|c|c|c|c|}
\hline \multirow{2}{*}{ Specification } & \multicolumn{3}{|c|}{ The intensity of technology level } \\
\hline & the lowest yield & the middle yield & the highest yield \\
\hline Direct surplus $\left(€\right.$ ha $\left.^{-1}\right)$ & 631.0 & 774.0 & 849.1 \\
\hline Direct surplus per $1 \mathrm{t}$ of product $(€)$ & 71.6 & 71.7 & 72.4 \\
\hline Direct costs per $1 €$ direct surplus & 0.40 & 0.39 & 0.38 \\
\hline Direct profitability index & 3.52 & 3.54 & 3.63 \\
\hline Direct surplus in \% of production value & 72.0 & 71.7 & 72.1 \\
\hline $\begin{array}{l}\text { Crop yield counterbalancing direct costs (t ha- } \\
\text { 1) }\end{array}$ & 1.9 & 2.3 & 2.5 \\
\hline
\end{tabular}

The relationship between the value of production and the direct costs plays a special role. This relationship is referred as the direct profitability index. In our own research, this indicator was high and very similar in the compared technologies. (3.52 in the lowest and 3.63 in the highest yield technology). Nachtman (2009) in organic technology of winter triticale achieved 8.7. While in Nasalski et al. (2008) researches an analogous index for winter wheat grown in a conventional system within the range of 1.2 and 1.8. However, the research by Jaśkiewicz (2006) indicates a higher value of this index in the technology with a lower level of nitrogen fertilisation The return of the direct costs in the lowest yield technology appeared at a unit yield of $1.9 \mathrm{t}$. In the highest yield technology, the costs were paid back when the yield of grain reached $2.5 \mathrm{t}$. The return of direct costs in the lowest yield technology occurred at yield of $1.9 \mathrm{t}$ in the highest yield technology was returned at grain yield of $2.5 \mathrm{t}$.

Table 5. Structure of the winter triticale direct costs production $(\%)$

\begin{tabular}{|c|c|c|c|}
\hline \multirow{2}{*}{ Specification } & \multicolumn{3}{|c|}{ The intensity of technology level } \\
\hline & the lowest yield & the middle yield & the highest yield \\
\hline Directs costs, including: & 100.0 & 100.0 & 100.0 \\
\hline mineral fertilizers & 50.3 & 59.2 & 61.5 \\
\hline grain sowing & 20.6 & 16.8 & 15.9 \\
\hline $\begin{array}{l}\text { plant protection products, } \\
\text { including: }\end{array}$ & 29.1 & 24.0 & 22.6 \\
\hline seed dressing & 3.6 & 3.0 & 2.8 \\
\hline fungicides & 14.6 & 12.0 & 11.3 \\
\hline herbicides & 10.9 & 9.0 & 8.5 \\
\hline
\end{tabular}

After analyzing the structure of direct costs incurred for the winter triticale production, it should be stated that mineral fertilisation was the highest share in both technologies and ranged from 30.3 to $61.5 \%$ of direct costs (Tab. 5). Literature reports confirm that mineral fertilization is the most costly element of technology and may exceed $60 \%$ of expenditure for production inputs (Dopka 2004). According to Domska et al. (2001), the level of fertilisation, especially nitrogen, determines the outlays on the crops production. Seed cost were the second most expensive direct cost item. In compared technologies, the cost was the same, however, in the cost structure, the discrepancy ranged from $22.6 \%$ in the highest yield technology to $29.1 \%$ in the lowest yield technology. The highest cost of using plant protection chemicals was fungicides.

\section{CONCLUSIONS}

1. The average values during 2013-2015 period, evidenced that the yields, 1,000 grain weight, grain number in ear and number of ears $\mathrm{m}^{-2}$ were highly statistically significantly different between the years $(P<0.05)$.

2. Effect of nitrogen and magnesium fertilisation on the grain yield and 1,000 grain weight was highly statistically significant. Increasing nitrogen doses caused reduction 1,000 grain weight.

3. The compared technologies were different in direct surplus value. The direct profitability index illustrating was similar in compared technologies, from 3.52 to 3.63. The highest yield technology ensured by $22.8 \%$ higher yield than the lowest yield technology. Mineral fertilisation is responsible for the highest share of direct costs in compared technologies.

4. The most favorable economic indexes were achieved in the highest yield technology. Production profitability (apart from volumes of yields achieved) strictly depends on grain prices and their relationship with the costs of production means.

\section{REFERENCES}

1. Alaru, M., Laur, Ü., Eremeev, V., Reintam, E., Selge, A., Noormets, M. 2009. Winter triticale yield formation and quality affected by $\mathrm{N}$ rate, timing and splitting. Agricultural and Food Science, Vol. 18, pp. 76-90.

2. Augustyńska-Grzymek, I. 2007. Produkcja, koszty i nadwyżka bezpośrednia uzyskana z działalności badanych w gospodarstwach konwencjonalnych w 2006 roku. Pszenżyto ozime. [w] Produkcja, koszty i nadwyżka bezpośrednia wybranych produktów 


\section{Proceedings of the $8^{\text {th }}$ International Scientific Conference Rural Development 2017}

rolniczych w 2006 roku. (Production, costs and gross margin recieved from the activities examined in conventional farms in 2006. Triticale. [in] Production, costs and gross margin of selected agricultural products in 2006. [red.] A. Skarżyńska. 60, pp. 43-55. [In Polish]

3. Biberdžić, M., Jelić, M., Knežević, B., Barać, S., Maksimović, G, Lalević, D. 2013. The effect of climatic conditions and variety on some morphological and productivity characteristics of triticale. Research Journal of Agricultural Science, Vol. 45(3), pp. 24-29.

4. Bielski, S. 2014. Economic efficiency of winter triticale grain production. Acta Scientiarum Polonorum, Oeconomia, Vol. 13(2), pp. 17-23.

5. Bielski, S. 2015. Yields of winter triticale under the influence of nitrogen fertilisation and fungicide application. Polish Journal of Natural Sciences, Vol 30(4), pp. 337-348.

6. Błaziak, J. 2007. Ocena zmian zawartości mikroelementów w zbożach pod wpływem wapnowania i magnezowania gleby. (Evaluation of microelement content changes in cereals under the influence of liming and magnesium) Ann. UMCS, Sec. E 62(1), pp. 77-84. [In Polish]

7. Chwil, S. 2014. Effects of foliar feeding under different soil fertilisation conditions on the yield structure and quality of winter wheat (Triticum aestivum L.). Acta Agrobotanica, Vol. 67 (4), pp. 135-144. https://doi.org/10.5586/aa.2014.059

8. Domska, D., Wojtkowiak, K., Sokołowski, Z. 2001. Efektywność produkcyjna nawożenia w uprawie pszenżyta. (The production efficiency of fertilisation in the cultivation of triticale). Agricultura, No. 89, pp. 29-34.

9. Dopka, D. 2004. Efektywność energetyczna zróżnicowanej uprawy przedsiewnej na przykładzie pszenżyta ozimego. (Energy effectiveness of differentiated pre-sowing cultivation based on an example of winter triticale). Annales UMCS, Vol. 59(4), pp. 2071-2077. [In Polish]

10. Dopka, D. 2006. Effect of nitrogen fertilisation and retardants on the yield of winter triticale. Zeszyty Naukowe Uniwersytetu PrzyrodniczoRolnictwo, 74-75, pp. 25-36.

11. Erekul, O., Köhn, W. 2006. Effect of weather and soil conditions on yield components and bread-making quality of winter wheat (Triticum aestivum L.) and winter triticale (Triticosecale Wittm.) varieties in North-East Germany. Journal of Agronomy and Crop Science, Vol. 192, pp. 452-464. https://doi.org/10.1111/j.1439-037X.2006.00234.X

12. Estrada-Campuzano, G., Miralles, D.J., Slafer, G.A. 2008. Genotypic variability and response to water stress of preand postanthesis phases in triticale. European Journal of Agronomy, Vol. 28(3), pp. 171-177. https://doi.org/10.1016/j.eja.2007.07.005

13. Estrada-Campuzano, G., Slafer, G.A., Miralles, D.J. 2012. Differences in yield, biomass and their components between triticale and wheat grown under contrasting water and nitrogen environments. Field Crops Research, Vol. 128, pp. 167-179. https://doi.org/10.1016/j.fcr.2012.01.003

14. Ficco, D.B.M., Riefolo, C. Nicastro, G., De Simone, V., Di Gesù, A.M., Beleggia, R., Platani, C., Cattivelli, L., De Vita, P. 2009. Phytate and mineral elements concentration in a collection of Italian durum wheat cultivars. Field Crops Research, Vol. 111, pp. 235-242. https://doi.org/10.1016/j.fcr.2008.12.010

15. Gibson, L.R., Nance, C.D., Karlen, D.L. 2007. Winter triticale response to nitrogen fertilisation when grown after corn or soybean. Agronomy Journal, Vol. 99, pp. 49-58. https://doi.org/10.2134/agronj2006.0195

16. Grabiński, J., Nieróbca, P., Szeleźniak, E. 2008. Wpływ intensywności produkcji na plonowanie zbóż w wadliwych płodozmianach. (Impact of production intensity on the yield of cereals in defective crop rotations). Zagadnienia ekonomiki rolnej. Instytut Ekonomiki Rolnictwa i Gospodarki Żywnościowej, No. 2, pp. 88-93.

17. Guoa, W., Nazimc, H., Lianga, Z., Yanga D. 2016. Magnesium deficiency in plants: An urgent problem. The Crop Journal, Vol. 4, pp. 83-91. https://doi.org/10.1016/j.cj.2015.11.003

18. Jankowski, K.J., Hulanicki, P.S., Sokólski, M., Hulanicki, P., Dubis, B. 2016. Yield and quality of winter wheat (Triticum aestivum L.) in response to different systems of foliar fertilisation. Journal of Elementology, Vo. 21(3), pp. 715-728.

19. Jaśkiewicz B. 2002. Określenie wymagań agrotechnicznych nowych odmian pszenżyta ozimego. (Determination of agrotechnical requirements for new winter triticale varieties). Biul. IHAR, Vol. 223/224, pp. 151-157.

20. Jaśkiewicz, B., 2006. Ekonomiczna efektywność produkcji półkarłowej formy pszenżyta ozimego. (Economic effectiveness of cultivation of semi-dwarf form of winter triticale). Pam. Put. Vol. 142, pp. 163-169. [In Polish]

21. Lestingi, A., Bovera, F., De Giorgio, D., Ventrella, D., Tateo, A. 2010. Effects of tillage and nitrogen fertilisation on triticale grain yield, chemical composition and nutritive value. Journal of the Science of Food and Agriculture, Vol. 90, pp. 2440-2446. https://doi.org/10.1002/jsfa.4104

22. Lipiński, W., 2000. Odczyn i zasobność gleb w świetle badań stacji chemiczno-rolniczych. (Soil pH and soil fertility in the light of the research of chemical and agricultural stations). Naw. Nawoż./Fert. Fertil. Vol. 3-4, pp. 89-105. [In Polish]

23. Mengutay, M., Ceylan, Y., Kutman, U.B., Cakmak, I. 2013. Adequate magnesium nutrition mitigates adverse effects of heat stress on maize and wheat. Plant and Soil, Vol. 368, pp. 57-72. https://doi.org/10.1007/s11104-013-1761-6

24. Mut, Z., Sezer, I., Gulumser, A. 2005. Effect of different sowing rates and nitrogen levels on grain yield, yield components and some quality traits of triticale. Asian Journal of Plant Sciences, Vol. 4, pp. 533-539. https://doi.org/10.3923/ajps.2005.533.539

25. Nachtman, G. 2009. Produkcja, koszty i nadwyżka bezpośrednia uzyskana z działalności badanych w 2008 roku. Produkcja roślinna. [w] Wyniki ekonomiczne wybranych ekologicznych produktów rolniczych w latach 2005-2008. (Production costs and gross margin achieved from the activities examined in 2008. Crop production. [in] The economic results of selected organic agricultural products in 2005-2008)., 141, pp. 18-31. [In Polish]

26. Nasalski, Z., Rychcik, B., Sadowski, T. 2008. Efektywność przestawiania uprawy roślin z metody konwencjonalnej na system rolnictwa ekologicznego. (Efficiency of change of plants cultivation from conventional to ecological agriculture system). Acta Sci. Polonorum, Oeconomia, Vol. 7(3), pp. 67-79. [In Polish] 
27. Nieróbca, P., Grabiński, J., Szeleźniak, E. 2008. Wpływ intensywności technologii uprawy zbóż w płodozmianie zbożowym na efektywność produkcyjną i ekonomiczną. (Influence of production technology intensity of grain species planted in cereal crop rotation on productive and economic effectiveness). Acta Scienarum. Polonorum, Agriculture, Vol. 7(3), pp. 73-80.

28. Podolska G., Sułek A., Stankowski S., 2002. Obsada kłosów, podstawowy parametr plonotwórczy pszenicy. (Spikes density, basic parameters of winter wheat yielding). Acta Scienarum. Polonorum, Agriculture, Vol. 1(2), pp. 5-14.

29. Samborski, S., Gozdowski, D., Rozbicki, J. 2008. Effect of nitrogen fertilisation on grain quality of traditional and short straw winter triticale varieties. Fragmenta Agronomica, Vol. 25(1), pp. 372-289.

30. Sienkiewicz, S., 1994. Reakcja zbóż na nawożenie magnezem. (Cereal response to magnesium fertilisation) Biul. Magnezol, No. 5, pp. 36-39.

31. Staugaitis, G., Rutkauskienè, R., 2010. Comparison of magnesium determination methods as influenced by soil properties. Zemdirbyste-Agriculture, No. 97, pp. 105-116.

32. Villegas, D., Casadesus, J., Atienza, S., Martos, V., Maalouf, F., Karam, F., Aranjuelo, I., Nogues S. 2010. Tritordeum, wheat and triticale yield components under multi-local mediterranean drought conditions. Field Crops Research, Vol. 116, pp. 68-74. https://doi.org/10.1016/j.fcr.2009.11.012

33. Zečevic, V., Knezevic, D., Boskovic, J., Milenkovic, S. 2010. Effect of nitrogen and ecological factors on quality of winter triticale cultivars. Genetika, Vol. 42(3), pp. 465-474. https://doi.org/10.2298/GENSR1003465Z 